\title{
Banks Performance in Ghana: Trends and Determinants
}

\author{
Paul Kwame Nkegbe \\ Department of Economics and Entrepreneurship Development, \\ Faculty of Integrated Development Studies, \\ University for Development Studies, \\ P.O. Box 520, Wa, Ghana. \\ Email:npkoo4@yahoo.com \\ and

\section{Yazidu Ustarz} \\ Department of Economics and Entrepreneurship Development, \\ Faculty of Integrated Development Studies, \\ University for Development Studies, \\ P.O. Box 520, Wa, Ghana. \\ Email:uyazidu@uds.edu.gh \\ DOI//http://dx.doi.org/10.4314/gjdsv12i1\&2.3
}

\begin{abstract}
The paper examines determinants of banks performance in the Ghanaian banking industry for the period 2000-2010 using trend graphs, equations and panel data estimation techniques. Three different measures of performance are employed and the results show a negative trend in banks performance within the study period. This observation is worrying due to the crucial role banks play in the economy. On the determinants, market share of loan is found to be positively related to performance, confirming the relative market power hypothesis. The results further reveal that banks in Ghana pass on their inefficiencies to their customers by raising their lending rates and lowering their deposit rates. The findings have some policy implications: banks should reduce the level of administrative overheads instead of passing their inefficiencies to their customers, as this has the effect of reducing the amount of credit customers would take for economic activities.
\end{abstract}

Keywords: Structure-Conduct-Performance Hypothesis, Market Power Theory, Return on Assets, Return on Equity, Net Interest Margin 


\section{INTRODUCTION}

The financial sector is crucial to the economies of various countries, and banks remain a core of the sector, especially in developing economies where the capital market is not strong enough (Matthew \& Laryea, 2012).The banking sector in Africa and the rest of the developing world has experienced major transformation in its operating environment. In a number of countries, financial sector reforms have been implemented. In Ghana, these started in the late 1980s as part of an ongoing Economic Recovery Programme (ERP). They began with the partial liberalisation of interest rates in 1987 and removal of sectoral credit ceilings the following year. This was accompanied by liberalisation of access to foreign exchange and the licensing of foreign exchange bureaux (Brownbridge \& Gockel, 1996). The Financial Sector Adjustment Programme (FINSAP) commenced in 1989, supported by a Financial Sector Adjustment Credit (FSAC) from the World Bank. The objectives of the FINSAP, inter alia, were to address the institutional deficiencies of the financial system, in particular by restructuring distressed banks, reforming prudential legislation and the supervisory system, permitting new entry into financial markets by public and private sector financial institutions, and developing money and capital markets (Brownbridge \& Gockel, 1996). In these reforms, the roles of banks remained central in financing economic activities in the various segments of the markets especially in sub-Saharan Africa (Athanasoglou, Delis \& Staikouras, 2006). Adequate performance of financial institutions measured in terms of profitability is of crucial importance not just to their customers but for their continued growth and survival (Bikker, 2010).

Despite the financial sector reforms in Africa since the 1990s with an aim of improving profitability, efficiency and productivity, commercial banks' performance has remained poor with substantial gaps in service delivery to private agents (Munyambonera, 2013). The study of profits is important not only because of the information it provides about the health of the economy in any given year, but also because profits are a key determinant of growth and employment in the medium-term. Changes in profitability are an important contributor to economic progress via the influence profits have on the investment and savings decisions of companies. This is because a rise in profits improves the cash flow position of companies and offers greater flexibility in the source of finance for corporate investment (Ayanda, Christopher \& Mudashiru, 2013).

The banking system in Ghana consists of a national network of licensed and statutory financial institutions engaged in the business of banking under the banking laws of Ghana. Bank of Ghana is the central bank and regulates the activities of all the banks. The number of Deposit Money Banks (DMBs) and Non-Bank Financial Institutions (NBFIs) stood at 26 and 52 respectively as at the end of 2012. Profitability in the banking sector has been mixed. Net interest margin (NIM) dropped from $9.6 \%$ to $6.5 \%$ by end of 2005 . By the close of 2009, the profitability ratios of the DMBs as measured by the return on assets (ROA), return on earning assets (ROEA) and return on equity (ROE) had seen some continuous decline since 2007. The banking industry in recent times however remained liquid, solvent and profitable over some time (BoG, 2012). The DMBs remained profitable 
with all the indicators showing improvement as compared to the previous year (see Table 1).

Table 1: Banks profitability indicators (\%)

\begin{tabular}{|l|l|l|l|l|}
\hline Indicators & $\mathbf{2 0 0 9}$ & $\mathbf{2 0 1 0}$ & $\mathbf{2 0 1 1}$ & $\mathbf{2 0 1 2}$ \\
\hline Return on Assets (ROA) & 2.8 & 3.8 & 3.9 & 4.9 \\
\hline Return on Earning Asset (ROEA) & 3.8 & 5.1 & 5.3 & 6.5 \\
\hline Return on Equity (ROE) & 17.5 & 20.4 & 19.7 & 25.8 \\
\hline Net Interest Spread (NIS) & 9.1 & 11.1 & 9.7 & 10.3 \\
\hline Cost to Income Ratio & 62.8 & 58.5 & 59.8 & 53.8 \\
\hline Net Interest Margin (NIM) & 10.8 & 12.4 & 10.2 & 10.9 \\
\hline
\end{tabular}

Source: Bank of Ghana, 2012

The survival and performance of banks is of much interest to policy makers and shareholders, and also to researchers (Krakah \& Ameyaw, 2010). Therefore, studies that seek to investigate the performance of banks and its determinants are vital to identifying the means of promoting the survival and growth of the sector that serves as the backbone of the financial system of developing economies (Matthew \& Laryea, 2012).

There are a number of studies in Ghana on banks performance. Krakah and Ameyaw (2010) examined the drivers of banks profitability using Ghana Commercial Bank Ltd and Merchant Bank Ltd. They found non-interest income, non-interest expense, bank's capital strength, total assets, growth of money supply, and annual rate of inflation as significant drivers of banks profitability. Given the fact that there are about 27 banks in Ghana, generalisation of the result on the sector could be misleading. Mills and Amowine (2013) also studied the determinants of Rural and Community Banks' (RCBs) financial profitability using a secondary data of 26 RCB for the period 2002 to 2011 . Given the varied characteristics (such as size, capital, credit risk, loan portfolios among others) between RCBs and the Deposit Money Banks (DMBs), there is the need for a study in this regard. The current study adds to existing knowledge by examining the trend in banks performance using both trend equations and graphs. Also, the study analyses determinants of banks performance using not just bank specific variables, but also industry and external variables. Given the fact that various banks use different measures to assess their performance, the current study departs from previous studies by using the three main measures of profitability, namely, ROA, ROE and NIM, as the dependent variables. ${ }^{1}$

1 Refer to Dependent Variables under 'Empirical Model' for definition as well as distinction of the three terms. 
The rest of the paper is organised as follows: Section 2 entails the review of relevant literature, Section 3 presents the methodology of the study, results of the study are discussed in Section 4 and the final section presents conclusions of the study.

\section{LITERATURE REVIEW}

Theories on determinants of bank performance are varied. Studies on performance have largely employed the structure-conduct-performance (SCP), and the market power hypotheses. The market structure, conduct and performance framework was derived from the neo-classical analysis of markets (Shaik, Allen, Edwards \& Harris, 2009). The concept of SCP asserts that market performance (profits, price and product quality) depends on market conduct (pricing behaviour, legal tactics, merger and collusion) that in turn depends on market structure (number of buyers and sellers, and barriers to entry) (Ahokpossi, 2013). Haron (1996) observed that the SCP theory was first used by researchers using manufacturing firm data and gained popularity among researchers in banking studies in the 196os, further expanded in the 1970 os and continued into the 1980 os. Another theory that explains banks performance is the market power (MP) theory or hypothesis. The MP theory states that increased external market forces result in profit. Moreover, the hypothesis suggests that only firms with large market share and well differentiated portfolio (product) can win their competitors and earn monopolistic profit (Ongore \& Kusa, 2013).

In banking literature, the determinants of profitability are empirically well explored although the definition of profitability varies among studies. While some studies focus on the understanding of bank profitability in a particular country, others concentrate their analysis on a panel of countries (Vong \& Chan, 2009). Govori (2013) observed that research studies on the determinants of banks profitability focus on returns on assets and equity and the net interest margin as measures of performance. Whether in-country or cross-country studies, Nassreddine, Fatma, and Anis (2013) argue that the determinants of banks performance can be split between those that are internal and those that are external. Internal determinants are also sometimes called microeconomic determinants or inherent performance, while external determinants are variables that reflect economic and legal environment in which the bank operates.

The internal factors are bank specific variables, which influence the profitability of specific banks. These factors are within the scope of the bank to manipulate and that they differ from bank to bank. These include capital size, size of deposit liabilities, size and composition of credit portfolio, interest rate policy, labour productivity, and state of information technology, risk level, management quality, bank size, and ownership, among others (Ongore \& Kusa, 2013).

External determinants, otherwise known as macroeconomic variables, on the other hand are variables that reflect economic and legal environment in which the bank operates (Nassreddine et al., 2013). Macroeconomic conditions may affect banking performance 
in a number of ways. Firstly, there will be a higher demand for bank credit in times of economic boom than in times of recession. A high aggregate growth rate may strengthen the debt servicing capacity of domestic borrowers, and therefore, contribute to less credit risk (Vong \& Chan, 2009). Alternatively, adverse macroeconomic conditions hurt banks by increasing the amount of non-performing loans.

Vong and Chan (2009) examined the impact of bank characteristics as well as macroeconomic and financial structure variables on the performance of the Macao banking industry. They found asset quality, as measured by the loan-loss provisions and the loan-to-total assets ratio, to adversely affect the performance of banks. On the contrary, management efficiency as measured by the ratio of equity to total assets was positively related to banks performance. They concluded that, a bank's performance can be improved if it is well capitalised and borrows less to finance its operations. With regard to macroeconomic variables, only the rate of inflation exhibits a significant relationship with banks performance.

Garza-Garcia (2011) analysed the determinants of bank performance in the Mexican banking sector for 2001-2009. The results of the study indicate that the lagged performance variable is positive and significant, which shows the tendency of bank profits to persist over time. Also, the Herfindahl-Hirschman index (HHI), which is a proxy for market concentration, shows no significance, thus rejecting the SCP hypothesis. The ratio of loan to total assets is negatively related to performance while capital is positive and significantly related to performance. Thus greater capital in banks reduces their funding costs and releases to them more resources to fund profitable investments.

Hoffmann (2011) examined the determinants of the profitability of US banks during the period 1995-2007. Contrary to Garza-Garcia (2011), their findings document a negative link between the capital ratio and the profitability, which supports the notion that banks are operating over-cautiously and ignoring potentially profitable trading opportunities. They also find a significant negative relationship between the size of the bank and its profitability. Thus a bank can take advantage of the scale economies at a low asset size level, but these scale economies become exhausted as the bank's size increases.

Ayanda et al. (2013) looked at the determinants of profitability in the Nigerian banking industry from 1980 to 2010. Applying the econometric analysis of cointegration and error correction techniques, they found capital adequacy and credit risk to be statistically significant and negatively related to profitability of loans. Efficiency management - which shows banks' ability to manage their cost in order to boost their profits - was, however, found to be positively related to net interest margin. For the external or macroeconomic variables, they found broad money supply growth rate to be a significant driver both in the long run and in the short run.

Sarita, Zandi and Shahabi (2012) examined the determinants of bank performance in Indonesia for the period 1994-1999 using pooled cross-sectional time series and dynamic panel data models. They established a negative and significant relationship between 
capital adequacy ratio, debt-to-total assets and bank performance. The findings, they argued, showed that bank performance was achieved not because of capital from the banks themselves, but from society's funds. Bank debt as debt-to-total assets also exhibited a negative relationship. The relationship between bank size and bank performance was positive implying that bank size increases bank performance.

Molyneux and Thornton (1992) examined the determinants of bank performance across eighteen European countries and found that state-owned banks generate higher returns on capital than their private sector competitors contrary to the findings in literature. They, however, attributed this to their sample which comprises a much larger proportion of state owned banks. Hassan and Bashir (2003) analysed how bank characteristics affect the performance of Islamic bank utilizing bank level data for 1994-2001, and found an inverse and statistically significant relationship between non-interest earning assets variable and performance measures. They also established significant positive relation of economic growth with performance measures.

Ahokpossi (2013) examined the determinants of bank interest margins in sub-Saharan African countries and found market concentration, bank inefficiency, equity and credit risk to be positively associated with interest margins. Liquidity ratio was negatively and significantly related to interest margins. Macroeconomic variables' relationship with bank performance in the study however appeared mixed. While inflation was positively related to interest margins, no evidence of significant relationship was found between economic growth and interest margins.

From the literature, it is evident that determinants of bank performance are varied both internally and externally and so also the measurement of performance (profitability). The findings in the literature guided the setting up of the empirical model for this study.

\section{METHODOLOGY}

\section{Theoretical Model}

The analysis of panel data is the subject of one of the most active and innovative bodies of literature in econometrics, partly because panel data provide such a rich environment for the development of estimation techniques and theoretical results (Greene, 2003). In panel data, the same cross-sectional unit is surveyed over time. Studies on banks performance either cross-country or country specific have largely relied on panel techniques.

Verbeek (2004) sets out the framework for panel study as:

$$
y_{i t}=\alpha+x_{i t}^{\prime} \beta_{i t}+\varepsilon_{i t}
$$


where $\beta_{i t}$ measures the partial effects of $x_{i t}$ in period $t$ for unit $i$. The standard assumption, used in many empirical cases, is that is constant for all and except possibly the intercept term. This could be written as:

$y_{i t}=\alpha_{i}+x_{i t}^{\prime} \beta+\varepsilon_{i t}$

where $x_{i t}$ is a $K$-dimensional vector of explanatory variables, not including a constant. This means that the effects of a change in are the same for all units and all periods, but that the average level for unit $i$ may be different from that for unit $j$. The $\alpha_{i}$ thus captures the effects of those variables that are peculiar to the th individual and that are constant over time. In the standard case $\varepsilon_{i t}$, is assumed to be independent and identically distributed over individuals and time, with mean zero and variance $\sigma_{\varepsilon}^{2}$ (Verbeek, 2004).

If it is assumed all individual differences are captured by differences in the intercept parameter $\left(\alpha_{i}\right)$, the model is referred to as the standard fixed effects model (FEM). If it is again assumed that all individual differences are captured by the intercept parameters, but also recognized that the individuals in the sample were randomly selected with mean $\mu$ and variance $\sigma_{\alpha}^{2}$, then the individual differences are treated as random rather than fixed (Judge et al., 1982), leading to random effects model (REM). The error term in this model consists of two components: a time-invariant component and a remainder component that is uncorrelated over time and can be written as:

$y_{i t}=\mu+x_{i t}^{\prime} \beta+\alpha_{i}+\varepsilon_{i t}$

where $\mu$ the in equation (3) also denotes the intercept term.

There are several advantages of working with panel data. Awunyo-Vitor and Badu (2012) observe that panel data facilitate identification of effects that cannot be detected using purely cross-section or time series data. According to Greene (2003), however, the fundamental advantage of a panel data set is that, it allows the researcher greater flexibility in modelling differences in behaviour across individuals.

\section{Estimation of Panel Data Regression Models}

The fixed versus random effects issue has generated a heated debate in the biometrics and statistics literature which has spilled over into the panel data econometrics literature (Baltagi, 2005). The challenge has been which model is better, FEM or REM? The answer to this question hinges on the assumption one makes about the likely correlation between the individual, or cross-section specific, error component and the $X$ regressors. If it is assumed that $e_{i}$ and the X's are uncorrelated, the REM may be appropriate, whereas if $e_{i}$ and the are correlated, FEM may be appropriate (Gujarati, 2004).

Judge, Hill, William, Lütkepohl .and Lee (1982), however, suggest the need to have a statistical test for the hypothesis that $e_{i}$ and the X's are uncorrelated. Hausman in 1978 developed a test to decide whether to use FEM or REM (Gujarati, 2004). If the 's are 
uncorrelated with the explanatory variables, the random effects estimator is consistent and efficient, and the fixed effect estimator is consistent but not efficient. On the other hand, if the $e_{i}$ 's are correlated with the explanatory variables, the fixed effects estimator is consistent and efficient but the random effects estimator is now inconsistent (Johnston \& Dinardo, 1997).

This difference sets up a clear case for a Hausman test, defined simply as:

$H=\left(\hat{\beta}_{R E}-\hat{\beta}_{F E}\right)^{\prime}\left(\Sigma_{F E}-\Sigma_{R E}\right)^{-1}\left(\hat{\beta}_{R E}-\hat{\beta}_{F E}\right)$

The null hypothesis underlying the Hausman test is that the FEM and REM estimators do not differ substantially. The test has an asymptotic $\chi^{2}$ distribution. If the null hypothesis is rejected, the conclusion is that REM is not appropriate and that we may be better off using FEM, in which case statistical inferences will be conditional on the in the sample (Gujarati, 2004).

\section{Empirical Model}

The study adopts the model used by Athanasoglou et al. (2006) as it incorporates the bank specific variables, the industry specific variables and the macroeconomic factors. They set out the general model in a linear form as:

$\Pi_{i t}=c+\sum_{k=1}^{k} \beta_{k} X_{i t}^{k}+\varepsilon_{i t}$

where $\Pi_{i t}$ is the profitability of bank $i$ at time $t$, with $i=1 \ldots, N ; t=1, \ldots, T, c$ is a constant term, $X_{i t}$ are $k$ explanatory variables and $\varepsilon_{i t}$ the disturbance term, with $v_{i}$ the unobserved bank-specific effect and $u_{i t}$ the idiosyncratic error. This is a one-way error component regression model, $v_{i} \sim \operatorname{IIN}\left(0, \sigma_{v}^{2}\right)$ where and independent of $u_{i t} \sim \operatorname{IIN}\left(0, \sigma_{u}^{2}\right)$. The explanatory variables $\left(X_{i t}\right)$ are grouped into bank-specific, industry-specific and macroeconomic variables. The general specification of model (1) with the $X_{i t}$ separated into these three groups is:

$\Pi_{i t}=c+\sum_{j=1}^{J} \beta_{j} X_{i t}^{j}+\sum_{l=1}^{L} \beta_{l} X_{i t}^{l} \sum_{m=1}^{M} \beta_{m} X_{i t}^{m}+\varepsilon_{i t}$

where the $X_{i t}$ with superscripts $j, l$ and $m$ denote bank-specific, industry-specific and macroeconomic determinants, respectively. Given the theoretical considerations, the empirical model to study the relationship between banks performance and its determinants is specified as:

$$
\begin{gathered}
\pi_{i t}=\alpha_{i t}+\beta_{1} L I Q_{i t}+\beta_{2} N P L_{i t}+\beta_{3} M S L_{i t}+\beta_{4} O P E R E F F I C_{i t}+\beta_{5} H H I_{-} A_{i t}+\beta_{6} \ln M 2_{i t} \\
+\beta_{7} \ln C P I_{i t}+\beta_{8} \ln G D P_{i t}+v_{i}+u_{i t}
\end{gathered}
$$

The definitions, notation and the expected sign of the variables used in the model are given in Table 2. Their description follows. 


\section{Dependent Variables}

Berger and Bouwman (2009) identified $R O E$ as a comprehensive profitability measure, since banks may have substantial off-balance sheet portfolios. Banks must allocate capital against every off-balance sheet activity in which they engage. Hence, net income and equity both reflect the bank's on - and off-balance sheet activities (Berger \& Bouwman, 2009). $R O E$ is a financial ratio that refers to how much profit a company earned compared to the total amount of shareholder equity invested or found on the balance sheet. ROE is what measures the return on shareholders' investment. A business that has a high return on equity is more likely to be one that is capable of generating cash internally. Thus, the higher the ROE the better the company is in terms of profit generation (Ongore \& Kusa, 2013).

Table 2: Definitions, notation and expected sign of the variables in the model

\begin{tabular}{|c|c|c|c|c|}
\hline \multicolumn{2}{|l|}{ Variable } & \multirow{2}{*}{$\begin{array}{l}\text { Measure } \\
\text { net profit/total equity } \\
\text { net profit/total assets } \\
\text { net interest income/ } \\
\text { total earning assets }\end{array}$} & \multirow{2}{*}{$\begin{array}{l}\text { Notation } \\
\text { ROE } \\
\text { ROA } \\
\text { NIM }\end{array}$} & \multirow{2}{*}{$\begin{array}{l}\text { Expected } \\
\text { sign }\end{array}$} \\
\hline $\begin{array}{l}\text { Dependent } \\
\text { variable }\end{array}$ & Profitability & & & \\
\hline $\begin{array}{l}\text { Bank specific } \\
\text { determinants }\end{array}$ & $\begin{array}{l}\text { Liquidity } \\
\text { Operational } \\
\text { efficiency } \\
\text { Non-performing } \\
\text { loans } \\
\text { Markets share } \\
\text { loan }\end{array}$ & $\begin{array}{l}\text { Net loans/total assets } \\
\text { Expense/income } \\
\text { Provision for bad debt/ } \\
\text { gross loan } \\
\text { Total loan/total loan of } \\
\text { all banks }\end{array}$ & $\begin{array}{l}\text { LIQ } \\
\text { OPEREFFIC } \\
\text { NPL } \\
\text { MSL }\end{array}$ & $\begin{array}{l}+ \\
- \\
- \\
+\end{array}$ \\
\hline $\begin{array}{l}\text { Industry specific } \\
\text { determinant }\end{array}$ & Concentration & $\begin{array}{l}\text { Herfindahl-Hirschman } \\
\text { index (the sum of the } \\
\text { squared market share } \\
\text { of assets of individual } \\
\text { banks) }\end{array}$ & HHI-A & + \\
\hline $\begin{array}{l}\text { Macroeconomic } \\
\text { determinants }\end{array}$ & $\begin{array}{l}\text { Gross domestic } \\
\text { product } \\
\text { Broad Money } \\
\text { supply } \\
\text { Consumer price } \\
\text { index }\end{array}$ & $\begin{array}{l}\text { Economic output } \\
\text { Total money in } \\
\text { circulation } \\
\text { Current consumer price } \\
\text { index }\end{array}$ & $\begin{array}{l}\text { GDP } \\
\mathrm{M} 2+ \\
\text { CPI }\end{array}$ & $\begin{array}{l}+ \\
+ \\
+/-\end{array}$ \\
\hline
\end{tabular}

$R O A$, on the other hand, reflects the management ability to utilize the bank's financial and real investment resources to generate profits. For any bank, ROA depends on the bank's policy decisions as well as uncontrollable factors relating to the economy and government 
regulations. Many regulators believe return on assets is the best measure of bank efficiency (Hassan \& Bashir, 2003).

NIM represents the amount by which the interest earned on a bank's portfolio exceeds the interest paid on deposits or borrowed funds. In the literature, NIM has emerged as a key indicator of asset productivity, since a high NIM is indicative of the effective use of earning assets and a sensible mix of interest-bearing liabilities (Brissimis, Delis \& Papanikolaou, 2008). Hence, the higher the NIM, the better the performance.

\section{Explanatory Variables}

\section{Bank and Industry Specific Variables}

$L I Q$, a measure of liquidity performance, is the ability to meet financial obligations as they become due and is crucial to the sustained viability of banking institutions (Kumbirai \& Webb, 2010). Very often, liquidity is measured by the ratio of loans to assets. The higher the ratio, the lower the bank's liquidity. In fact, the loan agreements have various maturities, and thus, in case of urgent need of capital, the bank cannot rely on these loans, since they will only be reimbursed later. The vast majority of authors found a positive relationship between this ratio and performance (Nassreddine et al., 2013).

NPL is a measure of capital risk, as well as credit quality. The main source of income is the interest earned on loans given to individuals and companies (Vong \& Chan, 2009). The ability to actually earn this interest depends on the bank's ability to recover the amount loaned including the interest amount. A negative relationship is expected between NPL and performance. If banks operate in more risky environments and lack the expertise to control their lending operations, it will probably result in a higher loan-loss provision ratio expected to impact negatively on bank performance (Vong \& Chan, 2009).

MSL, an indicator of size of the bank, is an important variable because large size is expected to promote economies of scale and reduce the cost of gathering and processing information. A positive relationship is posited between MSL and banks performance because large-sized banks have the advantage of providing a larger menu of financial services to their customers, and hence mobilize more funds (Nassreddine et al., 2013). In the literature, bank size is measured either in terms of the bank's total assets or the bank's share of the total loan in the industry. This study used the market share of loan as a proxy for size because the value of total assets has been used in the computation of most ratios, which could lead to collinearity problems.

OPEREFFIC, the ratio of overhead to total assets, is used to provide information on variation in operational costs across the banking system. It reflects employment, total amount of wages and salaries as well as the cost of running branch office facilities. A high ratio is expected to impact performance negatively because efficient banks are expected to operate at lower costs (Hassan \& Bashir, 2003). 
HHI-A is used to proxy the level of market concentration because it reflects the degree of market share inequality across the spectrum of firms that participate in a market (Schumann, 2011). It emerged from the structure-conduct-performance (SCP) theory and is based on the proposition that market concentration fosters collusion among firms. The assumption is that the degree of concentration in a market exerts a direct influence on the degree of competition among its firms. Highly concentrated markets will lower the cost of collusion and foster tacit and/or explicit collusion on the part of firms. As a result of this collusion, all firms in the market earn monopoly rents (Haron, 1996). It ranges from zero to one, where large number of banks, each with a small share, produces an HHI close to zero, while a single monopolist bank with a 100 percent share produces an $H H I$ of one. Maudos and Nagore (2005) observe that theoretically the HHI is superior to absolute market concentration measures such as market shares of the big three or five banks in the economy (otherwise known as $\mathrm{CR}_{3}$ or $\mathrm{CR}_{5}$ ) as such absolute measures only take into consideration the market share of the largest banks.

\section{Macroeconomic Variables}

Flamini, McDonald and Schumacher (2009) observed that the impact of macroeconomic variables on bank risk has recently been highlighted in the literature. Bank performance is expected to be sensitive to macroeconomic control variables. Accordingly, the study included three macroeconomic variables, namely, gross domestic product, inflation proxied by consumer price index and money supply. Natural logs of these variables were used so as to control for variation over time and also to be able to interpret the coefficients as elasticity.

Macroeconomic conditions may affect banking performance in a number of ways. Firstly, there will be a higher demand for bank credit in times of economic boom than in times of recession. A high aggregate growth rate may strengthen the debt servicing capacity of domestic borrowers, and therefore, contribute to less credit risk. Alternatively, adverse macroeconomic conditions hurt banks by increasing the amount of non-performing loans. Thus, it is expected that an improvement in economic growth helps bank performance (Vong \& Chan, 2009).

According to Naceur (2003), high inflation rates are generally associated with high loan interest rates, and therefore, high incomes. However, if inflation is not anticipated and banks are sluggish in adjusting their interest rates then there is a possibility that bank costs may increase faster than bank revenues and hence adversely affect bank profitability. The direction of the relationship therefore depends on the ability of banks to correctly anticipate the rate of inflation.

Money supply is expected to impact positively on bank performance. Increase in money supply is likely to increase deposits, which will increase the amount of loanable funds available for intermediation activities. 


\section{Data Sources}

The study employs annual bank level data from 2000 to 2010 for 27 banks in Ghana. ${ }^{2}$ This was obtained from the Bank of Ghana. Table 3 shows the descriptive statistics of the variables used in this study.

Table 3: Descriptive statistics of variables

\begin{tabular}{|l|l|l|l|l|l|}
\hline Variable & Observations & Mean & Std.Dev. & Minimum & Maximum \\
\hline ROA & 224 & 0.0199 & 0.0400 & -0.2091 & 0.1538 \\
\hline ROE & 224 & 0.1724 & 0.4443 & -4.5249 & 2.0880 \\
\hline NIM & 224 & 0.0784 & 0.0393 & 0.0146 & 0.3035 \\
\hline LIQ & 224 & 0.3897 & 0.1456 & 0.0403 & 0.8007 \\
\hline NPL & 224 & -0.6445 & 6.3270 & -89.6557 & 0.0788 \\
\hline MSL & 224 & 0.0497 & 0.0566 & 0.0000 & 0.3417 \\
\hline OPEREFFIC & 224 & -0.5911 & 0.5377 & -4.1446 & 3.6010 \\
\hline HHIA & 224 & 0.1004 & 0.0242 & 0.0637 & 0.1466 \\
\hline $\operatorname{lnCPI}$ & 224 & 5.4369 & 0.2688 & 4.9309 & 5.8342 \\
\hline $\operatorname{lnM} 2+$ & 224 & 22.2789 & 0.9744 & 20.4014 & 23.7760 \\
\hline $\ln$ GDP & 224 & 20.0578 & 1.9805 & 17.5913 & 22.1647 \\
\hline
\end{tabular}

From Table 3, there are interesting insights on the descriptive statistics of the variables used in this study. The ROA, ROE and NIM which proxy performance show averages of 0.02, 0.17 and 0.08 respectively. This shows that on the average, return on equity is higher than the other measures of performance. Interestingly, ROE has the minimum return of -4.5 and the maximum return of about 2.1. The minimum profit was as a result of negative profit recorded by Amalgamated Bank in 2010 while the maximum value was due to Stanbic's profit recorded in 2007. The deviation from the mean return for ROA and NIM appeared to be lower compared to the ROE, which shows some stability in ROA and NIM. $H H I$, which is an industry variable, shows an average of 0.10 with a minimum value of 0.06 and a maximum of 0.15 which suggests little concentration and hence a significant degree of diversification in the industrial assets.

For the bank specific variables, it is little surprising that NPL appeared highly volatile and unstable with a deviation of 6.3270 from the mean (-0.64), with a minimum of - 89.6557 and a maximum of 0.0788 . No wonder it remains a key factor affecting banks performance. For the macroeconomic variables, $\ln G D P$ appeared to be the most volatile

2 List of specific banks is available from the authors on request. 
with a standard deviation of 1.9805 . The $\ln C P I$ appeared to be the least volatile with a standard deviation of 0.2688 and a mean of 5.44 .

\section{EMPIRICAL RESULTS}

The results in this study are in two parts; the first part shows the trend in performance using both trend equations and graphs. The second part employs the panel technique to examine the determinants of banks performance.

\section{Trend in Banks Performance}

Trend equations make it possible for the magnitudes of the effects of the trends to be known, an important requirement for policy purposes. Again, this method is so sensitive that it picks up small trend effects (Nkegbe \& Kuunibe, 2014). The results are presented in Table 4 and Figure 1.

Table 4: Trend equation for performance measures

\begin{tabular}{|l|l|l|l|l|}
\hline Variable & Coefficient & Probability & R-squared & Trend \\
\hline AVROE & $-4.2500^{* * *}$ & 0.001 & 0.6954 & Decreasing \\
\hline AVROA & $-0.8073^{* * *}$ & 0.001 & 0.7527 & Decreasing \\
\hline AVNIM & 0.0400 & 0.785 & 0.0087 & Increasing \\
\hline
\end{tabular}

Note: ${ }^{* * *}$ denotes statistical significance at $1 \%$.

From Table 4, the general trend is that of a decreasing performance as shown by the coefficient of both average ROE and ROA. Interestingly, NIM which has a positive sign is not significant both in statistical terms and in value as shown by the probability and the $\mathrm{R}$-squared values. The fall in performance between 2000 and 2010 is further reinforced by the trend graphs shown in Figure 1. The fall in banks performance should be a source of concern for both management and policy makers due to the critical role banks play in the development of the economy. 


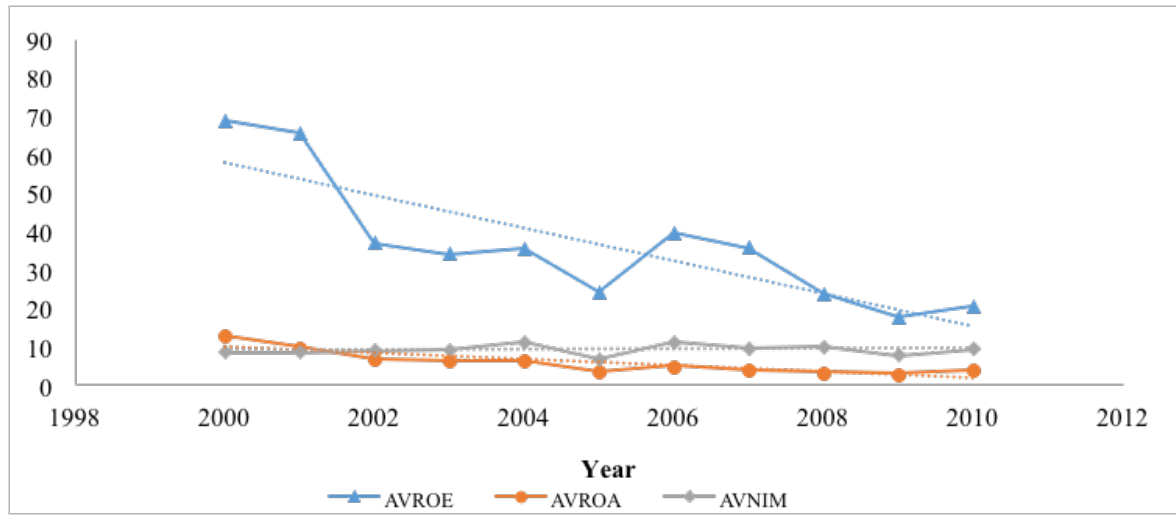

Figure 1: Trend graphs of return on equity, return on asset and net interest margin

\section{Determinants of Performance}

Table 5 reports the empirical results of the estimation of model (6) using return on assets $(R O A)$, return on equity (ROE) and net interest margin (NIM) as the profitability variables. The models' diagnostics show the models failed the test of heteroscedasticity (as shown by the Hettest values and the corresponding chi-square probability values in Table 5). This is the Breusch-Pagan/Cook-Weisberg test for heteroscedasticity. Brooks (2008) argues the presence of heteroscedasticity implies that though the estimates are unbiased, the estimators no longer have the minimum variance among the class of unbiased estimators. The study therefore employed the panel corrected standard error technique for the estimations, thus the standard errors reported in Table 5 are corrected. In terms of model performance, ROA has an R-squared value of about $27 \%$ followed by NIM (16\%) and ROE $(16 \%)$. It is important to point out though that since a panel approach is used, emphasis is placed on the significance of the Wald values, which show the explanatory variables taken together are important in explaining banks performance across the three models.

The variable liquidity (LIQ) is positive and statistically significant in all the models and also in line with expectation. It has a value of $0.038 \%$ in $R O A, 0.33 \%$ in $R O E$ and $0.02 \%$ for NIM. Thus a percentage increase in LIQ leads to an increase in ROA, ROE and NIM by $0.038 \%, 0.33 \%$ and $0.02 \%$ respectively. Adequate liquidity helps banks to minimise the effect of liquidity risk and financial crises by absorbing any possible unforeseen shocks. This is in line with the findings of Ongore and Kusa (2013). 
Table 5: Determinants of profitability

\begin{tabular}{|c|c|c|c|c|c|}
\hline \multirow[b]{2}{*}{ Variable } & \multicolumn{2}{|l|}{$\mathrm{ROA}$} & \multirow{2}{*}{$\begin{array}{l}\text { ROE } \\
\text { Coefficient }\end{array}$} & \multicolumn{2}{|l|}{ NIM } \\
\hline & Coefficient & $\begin{array}{l}\text { Panel } \\
\text { corrected } \\
\text { std. error }^{\dagger}\end{array}$ & & Coefficient & $\begin{array}{l}\text { Panel } \\
\text { corrected std. } \\
\text { error }\end{array}$ \\
\hline Constant & $0.1102^{* * *}$ & 0.0170 & $2.3098^{* * *}$ & $0.2570^{* * *}$ & 0.0325 \\
\hline LIQ & $0.0378^{* * *}$ & 0.0138 & $0.3332^{* * *}$ & $0.0245^{* *}$ & 0.0102 \\
\hline NPL & $-0.0001^{* *}$ & 0.0000 & $-0.0018^{* * *}$ & 0.0000 & 0.0001 \\
\hline MSL & $0.1256^{* * *}$ & 0.0263 & $1.3726^{* * *}$ & $0.0905^{* * *}$ & 0.0263 \\
\hline OPEREFFIC & $0.0249^{* * *}$ & 0.0068 & $0.12659^{* *}$ & $0.0065^{* * *}$ & 0.0020 \\
\hline HHIA & $-0.1280^{* * *}$ & 0.0359 & $0.5908^{* * *}$ & 0.0331 & 0.0464 \\
\hline $\ln C P I$ & $0.0074^{* *}$ & 0.0032 & $-0.2075^{* * *}$ & $0.0123^{*}$ & 0.0070 \\
\hline $\ln \mathrm{M}_{2+}$ & $-0.0014^{* * *}$ & 0.0004 & $-0.0478^{* * *}$ & $-0.0086^{* * *}$ & 0.0013 \\
\hline $\ln G D P$ & $-0.0047^{* * *}$ & 0.0012 & -0.0064 & $-0.0034^{* *}$ & 0.0017 \\
\hline \multicolumn{6}{|l|}{ Diagnostics } \\
\hline R-squared & \multicolumn{2}{|c|}{0.27} & 0.16 & \multicolumn{2}{|c|}{0.16} \\
\hline Wald (8) & \multicolumn{2}{|c|}{4988.65} & 6640.89 & \multicolumn{2}{|c|}{14278.19} \\
\hline Prob> & \multicolumn{2}{|c|}{0.0000} & 0.0000 & \multicolumn{2}{|c|}{0.0000} \\
\hline Hettest & \multicolumn{2}{|c|}{117.61} & 14.23 & \multicolumn{2}{|c|}{50.91} \\
\hline Prob> & \multicolumn{2}{|c|}{0.0000} & 0.0002 & \multicolumn{2}{|c|}{0.0000} \\
\hline No. of Banks & \multicolumn{2}{|c|}{27} & 27 & \multicolumn{2}{|c|}{27} \\
\hline Observations & \multicolumn{2}{|c|}{224} & 224 & \multicolumn{2}{|c|}{224} \\
\hline
\end{tabular}

Notes: ${ }^{* *},{ }^{* *}$, and ${ }^{*}$ indicate statistical significance at $1 \%, 5 \%$ and $10 \%$ levels respectively. $†$ As the models failed the test of heteroscedasticity, the pooled effects model with panel corrected standard error was used for the estimation instead of the traditional random or fixed effects models.

Non-performing loans variable (NPL) is significant in all the models. It is negatively related to $R O A$ and ROE, as expected, but positively related to NIM. Thus high non-performing loans result in poor bank performance probably due to the fact that loans constitute the largest share of assets that generate income for banks' investment (Ongore \& Kusa, 2013). Garza-Garcia (2011) who found a positive relationship between NPL and bank performance opined that firms performance increase with credit risk possibly by transferring this cost to the final consumer.

The bank size (MSL) coefficient is positive and significant in all three models, as expected, confirming the relative market power hypothesis. Therefore, banks with greater market share obtain higher profits by pricing above competitive levels. The figure is higher for ROE (1.37) compared to 0.13 for ROA and 0.09 for NIM. Thus banks with high market share 
are larger and generally benefit from economies of scale, which translates into higher efficiency. If this is not properly accounted for, the market share variable may be biased by the indirect effect of inefficiency (Ahokpossi, 2013).

Operational efficiency (OPEREFFIC) as a measure of efficiency shows positive and significant relationship with all the performance indicators, contrary to our expectation. Ahokpossi (2013), however, explained that inefficient banks pass their high costs on to their customers, raising their lending rates and lowering their deposit rates thereby improving their performance indicators. Bawumia, Belnye and Ofori (2009) affirmed this position in their study and reported that high operating cost contributes to wide spread in the interest rate. In offering evidence to the existence of wide interest rate spread, Kwakye (2010) observed that while lending rates in the Ghanaian banking industry averaged 30.63 percent at end of June 2010 (with a range from 23.5 percent to 37.5 percent), savings deposit rates averaged 7.25 percent (ranging from 2.0 percent to 11.5 percent).

Market concentration as proxied by $H H I$ is positively and significantly associated with $R O E$ supporting the SCP hypothesis. It is, however, negatively related to ROA which is contrary to our expectation, but signalling that dominant banks lower their interest margins temporarily to ward off competition. The positive relationship implies a direct relationship between the cost of intermediation and the banks' profit. Both the market-power hypothesis and the efficient-structure hypothesis support this argument. According to the market-power hypothesis, an increase in the market power yields monopolistic profits. The collusion hypothesis, whereby banks can collude either implicitly or explicitly to gain abnormal profits, supports the same conclusion (Hoffmann, 2011).

The macroeconomic variables show varied results. The coefficient on inflation $(\ln C P I)$ is positive and significant for ROA and NIM equations but negative for the ROE. This could be due to the fact that $R O E$ is an internal measure of performance which disregards the greater risks associated with high leverage compared to the ROA and NIM which take into consideration the risk factor. Indeed, domestic banks are fairly able to anticipate inflation so that higher levels of inflation are associated with higher interests and thus profitability in terms of ROA and NIM. However, they still need to strengthen their ability to target inflation properly since it is negatively associated with ROE. On the other hand, the coefficient on InGDP although negatively related to performance, is only significant in $R O A$ and NIM models. Thus banks did not benefit from the economic growth within the period of the study. Contrary to expectation, $\ln M 2+$ shows significant but negative relationship with all the three performance measures, possibly suggesting that banks did not benefit from market expansion within the study period. 


\section{CONCLUSIONS}

The results from the trend equations and graphs show a general decreasing trend in bank performance indicators (return on equity, return on assets and net interest margin). On determinants of banks performance, the study finds liquidity, market share of loan and operational efficiency to be positively related to all the performance indicators. Non-performing loan is, however, significant and negatively related to only return on equity and return on assets. On the macroeconomic determinants, money supply is also negatively related to all the performance measures while gross domestic product though negatively related to all performance indicators, is only significant in the case of return on assets and net interest margins.

The conclusions derived from the study have some policy implications for actors in the banking industry. The three measures of performance complement one another. $R O E$ is an internal measure of performance which fails to account for risk or leverage, which is addressed by ROA. The net interest margin (NIM) is able to capture the effect of the income generation capacity of the intermediation function of banks. It is therefore crucial for banks to measure their performance using all these measures instead of relying on one measure which could be misleading.

As stated earlier, the behaviour of the relationship between inflation and net returns on equity $(R O E)$ calls for further strengthening of banks' ability to anticipate inflation properly. Also, contrary to the a priori expectation, money supply is negatively related to all three indicators of banks performance in the Ghanaian economy. This is most likely the upshot of a situation where a greater proportion of the population is outside the formal banking sector. Banks should therefore intensify their savings mobilisation drive.

Non-performing loan (NPL) is becoming a key problem affecting banks performance as shown by the results of this study. A combination of factors could be adopted to combat this. The banks could offer training on how to prepare basic financial statements, especially when dealing with an informal sector that largely does not keep record. This is very important because banks could only do effective monitoring by relying on the financial statements prepared. Most borrowers from this sector only get people to prepare financial statements for them when going in for loans. The monitoring system should be revised to include regular submission of financial statements of borrowers. This would enable the banks to pick early signals on the possibility of loans going bad compared to a situation where banks demand financial statements only at the time clients are making request. 


\section{References}

Ahokpossi, c. (2013). Determinants of Bank Interest Margins in Sub-Saharan Africa. International Monetary Fund Working Paper No. 1334, Washington, D.C.

Athanasoglou, P., Delis, M.D. and Staikouras, C.K. (2006). Determinants of Bank Profitability in the South Eastern European Region. Bank of Greece WP 47, Economic Research Department, Athens.

Awunyo-Vitor, D. and Badu, J. (2012). Capital structure and performance of listed banks in Ghana. Global Journal of Human Social Science, 12(5), pp.57-62.

Ayanda, A.M., Christopher, E.I. and Mudashiru, M.A. (2013). Determinants of banks' profitability in a developing economy: evidence from Nigerian banking industry. Institute of Interdisciplinary Business Research, 4(9), pp.155-181.

Baltagi, B.H. (2005). Econometric Analysis of Panel Data (3rd ed.). UK: Wiley \& Sons Ltd.

Bawumia, M., Belnye, F. and Ofori, E.M. (2005). The Determination of Bank Interest Spreads in Ghana: An Empirical Analysis of Panel Data. Bank of Ghana, WP/MPAD/ BOG-05/o9.

BoG (2012). Annual Report. Accra: Bank of Ghana.

Berger, A.N. and Bouwman, C.H.S. (2009). Bank liquidity creation. The Review of Financial Studies, 22(9), pp.3779-3837.

Bikker, J.A. (2010). Measuring performance of banks: an assessment. Journal of Applied Business and Economics, 11(4), pp.141-159.

Brissimis, S.N., Delis, M.D. and Papanikolaou, N.I. (2008). Exploring the Nexus between Banking Sector Reform and Performance: Evidence from Newly Acceded EU Countries. Bank of Greece Euro System Working Paper 73, Athens.

Brooks, C. (2008). Introductory Econometrics for Finance. Cambridge: Cambridge University Press.

Brownbridge, M. and Gockel, A.F. (1996). The Impact of Financial Sector Policies on Banking in Ghana. Institute of Development Studies WP 38.

Flamini, V., McDonald, C. and Schumacher, L. (2009). The Determinants of Commercial Bank Profitability in Sub-Saharan Africa. International Monetary Fund WP/og/15, Washington, D.C.

Garza-Garcia, J.G. (2011). Determinants of Bank Performance in Mexico: Efficiency or Market Power. Centre for Global Finance Working Paper Series, Paper Number 03, Bristol. 
Govori, F. (2013). The Performance of Commercial Banks and the Determinants of Profitability: Evidence from Kosovo, MPRA Paper No. 46824.

Greene, W.H. (2003). Econometric Analysis (5th ed.). New Jersey: Pearson Education, Inc.

Gujarati, D.N. (2004). Basic Econometrics (4th ed.). New York: The McGraw-Hill Companies.

Haron, S. (1996). Competition and other external determinants of the profitability of Islamic banks. Islamic Economic Studies, 4(1), pp.49-64.

Hassan, M.K. and Bashir, A.H.M. (2003). Determinants of Islamic banking profitability. Paper presented at the 1oth ERF Annual Conference, Morocco, 16-18 December.

Hoffmann, P.S. (2011). Determinants of the profitability of the US banking industry. International Journal of Business and Social Science, 2(22), pp.255-269.

Johnston, J. and Dinardo, J. (1997). Econometric Methods (4th ed.). New York: McGrawHill Companies.

Judge, G.G., Hill, R.C., William, E., Lütkepohl, H. and Lee, T.C. (1982). Introduction to the Theory and Practice of Econometrics. New York: John Wiley \& Sons.

Krakah, A.K. and Ameyaw, A. (2010). The Determinants of Bank's Profitability in Ghana, The Case of Merchant Bank Ghana Limited (MBG) and Ghana Commercial Bank (GCB). Unpublished MBA Thesis, Blekinge Institute of Technology.

Kumbirai, M. and Webb, R. (2010). A financial ratio analysis of commercial bank performance in South Africa. African Review of Economics and Finance, 2(1), pp. 3053.

Kwakye, J.K. (2010). High Interest Rates in Ghana: A Critical Analysis. IEA Monograph No. 27. The Institute of Economic Affairs, Accra.

Matthew N.G. and Laryea, A.E. (2012). A financial performance comparison of foreign vs local banks in Ghana. International Journal of Business and Social Science, 3(21), pp.82-87.

Maudos, J. and Nagore, A. (2005). Explaining Market Power Differences in Banking: A CrossCountry Study (online). Available: www.uv.es/ maudosj/documentos/maudos\%20 and\%2onagore-final\%2oversion.pdf. Date accessed: 11 December 2014.

Mills, E.F.E.A. and Amowine, N. (2013). The rural bank profitability nexus: evidence from Ghana.International Journal of Application or Innovation in Engineering and Management, 2(4), pp.506-513. 
Molyneux, P. and Thornton, J. (1992). Determinants of European bank profitability: a note. Journal of Banking and Finance, 16(6), pp.1173-1178.

Munyambonera, E.F. (2013). Determinants of commercial banks' profitability in subSaharan Africa. International Journal of Economics and Finance, 5(9), pp.134-147.

Naceur, S.B. (2003). The Determinants of the Tunisian Banking Industry Profitability; Panel Evidence (online). Available: http://www.mafhoum.com/press6/174E11.pdf. Date accessed: 1 April 2014 .

Nassreddine, G., Fatma, S. and Anis, J. (2013). Determinants of banks performance: viewing test by cognitive mapping technique a case of Biat. International Review of Management and Business Research, 2(1), pp. 20-36.

Nkegbe, P.K., and Kuunibe, N. (2014). Climate Variability and Household Welfare in Northern Ghana. WIDER Working Paper No. 2014/o27, UNU-WIDER, Helsinki, Finland.

Ongore, V.o. and Kusa, G.B. (2013). Determinants of financial performance of commercial banks in Kenya. International Journal of Economics and Financial Issues, 3(1), pp.237-252.

Sarita, B., Zandi, G.R. and Shahabi, A. (2012). Determinants of performance in Indonesian banking: across-sectional and dynamic panel data analysis. International Journal of Economics and Finance Studies, 4(2), pp. 41-55.

Schumann, L. (2011). Measuring Market Concentration (online). Available: http://www. adbi.org/files/2011.05.10.cpp.day2.1.schumann.measuring.market.concentration. pdf. Date accessed: 14 December 2014.

Shaik, S., Allen, A.J., Edwards, S. and Harris, J. (2009). Market structure conduct performance hypothesis revisited using stochastic frontier efficiency analysis. Journal of the Transportation Research Forum, 48(3), pp.5-18.

Verbeek, M. (2004). A Guide to Modern Econometrics (2nd ed.). England: John Wiley \& Sons Ltd.

Vong, A.P.I. and Chan, H.S. (2009). Determinants of Bank Profitability in Macao(online. Available: $\quad$ www.amcm.gov.mo/publication/quarterly/July2oog/macaoprof_ en.pdf.Date accessed: 11 March 2014. 